Dariusz Jarosz

Warszawa

\title{
Sprawy książki polskiej i jej autorów w sowieckich dokumentach partyjnych $\mathrm{z}$ lat 1954-1971
}

W dotychczasowych badaniach nad dziejami książki polskiej w okresie powojennym temat jej funkcjonowania w komunistycznym systemie władzy poruszany był zwykle w kontekście polityki wewnętrznej. Najczęściej pisano o problemach związanych z cenzurą oraz jej omijaniem przez rozwój tzw. drugiego obiegu wydawniczego. Trudno w istniejącej literaturze przedmiotu znaleźć jakiekolwiek bogato udokumentowane studia, które koncentrowałyby się na wpływie Kremla na polski ruch wydawniczy. Mało wiemy również o tym, jak z perspektywy Kremla oceniano polską książkę i jej autorów, oraz co budziło szczególne zainteresowanie.

Ta biała plama w badaniach wchodzących w zakres bibliologii politycznej (i - szerzej - historii kultury) to efekt nie tyle zaniechań polskich naukowców, co trudności w dostępie do odpowiednich materiałów źródłowych. Archiwa państwowe w Rosji są obecnie trudne do sforsowania dla polskich historyków (i nie tylko dla nich). Okres odwilży za prezydentury Borysa Jelcyna już dawno się skończył. To, co wówczas wydano (głównie materiały źródłowe), ma tę wadę, że najczęściej sięga tylko do roku 1953, tj. do śmierci Stalina. W Rosji putinowskiej historia najnowsza jest orężem bieżącej walki politycznej, co w przypadku badań nad najnowszymi dziejami Polski oznacza szczególne trudności w dostępie do interesujących archiwaliów.

$\mathrm{W}$ tej sytuacji wprowadzanie do obiegu naukowego pochodzących $\mathrm{z}$ archiwów rosyjskich materiałów źródłowych wydaje się mieć specjalne znaczenie nawet przy świadomości, że dokonane w tych warunkach kwerendy najpewniej obejmują jedynie niewielką część przechowywanych tam dokumentów.

W przypadku niniejszego artykułu podstawą źródłową poczynionych ustaleń są nieliczne odtajnione archiwalia przechowywane w Rosyjskim Państwowym Archiwum Historii Najnowszej (Российский 
государственный архив новейшей истории - RGANI), pochodzące z potężnego zespołu akt sowieckiej partii komunistycznej. Udało się dotrzeć do niektórych materiałów dotyczących spraw wydawniczych, książek i ich autorów z lat 1954-1971. Choć z polskiego punktu widzenia obie cezury są trudne do uzasadnienia w oparciu o szerszy kontekst historyczny, mimo to zdecydowałem się je zastosować. Sądzę bowiem, że zapoznanie się ze znalezionymi materiałami pokazuje pewną ciagłość myślenia kierownictwa kremlowskiego o podjętej w tym szkicu problematyce. Niezmienne pozostają w generalnych założeniach również ideologiczne kryteria ocen książek i ich autorów.

\section{Główny przedmiot zainteresowań: polscy literaci i ich dzieła}

Odtajnione dokumenty zdają się świadczyć, że sowieckie kierownictwo partyjne i państwowe zajmowało się przede wszystkim polską książką literacką i środowiskiem pisarzy. Szczególne zainteresowanie budziła organizacja twórcza pisarzy - Związek Literatów Polskich (ZLP).

To właśnie tej problematyce został poświęcony obszerny dokument stanowiący sprawozdanie z podróży służbowej do Polski R. Orłowej, adresowany do redaktora naczelnego czasopisma „Innostrannaja litieratura". Autorka tego tekstu przebywała w Polsce od 22 kwietnia do 6 maja 1956 r. Spotkała się zarówno z polskimi literatami, jak i wydawcami.

W podsumowaniu tych rozmów zwracała uwagę przede wszystkim na powszechne narzekanie swych interlokutorów na niskie honoraria i złe warunki mieszkaniowe. W kontaktach z pisarzami przyszło Orłowej zetknąć się z różnymi problemami stosunków polsko-sowieckich. Redaktor Państwowego Instytutu Wydawniczego Irena Szymańska poinformowała ją o planach wydawnictwa i stwierdziła, że nadszedł czas, aby zdjąć dziesięcioletni zakaz publikowania prac o powstaniu warszawskim. Polscy rozmówcy krytykowali Towarzystwo Przyjaźni Polsko-Radzieckiej za lansowanie lukrowanego obrazu ZSRR. Nie podobał im się Pałac Kultury i Nauki ze względów estetycznych i drożyzny jego wykonania. Autorka relacji nie ignorowała uwag krytycznych. Całościowo oceniała jednak, że „,co prawda zdarzały się wypowiedzi antyradzieckie, ale polska inteligencja, jak można sądzić z rozmów, jest przeniknięta głęboką miłością do naszego kraju”.

Orłowa twierdziła, że polscy literaci walczą przeciwko administracyjno-biurokratycznemu kierowaniu literatura, przeciwko schematyzmowi i dogmatyzmowi. Przy okazji charakterystyki ich postawy politycznej najwyżej oceniała Stefana Żółkiewskiego i Jerzego Putramenta, którzy 
„stoją bez watpienia na partyjnych pozycjach”, choć poddawali oni ostrej krytyce i samokrytyce charakter partyjnego kierowania literatura.

W grupie pisarzy i krytyków odrzucających socrealizm i żądających swobody twórczości lokowała Adama Ważyka, Julina Przybosia, Antoniego Słonimskiego i Jana Kotta. Polscy pisarze mieli jej zdaniem powszechnie krytykować Leona Kruczkowskiego, „którego uznają za wielmożę i czynownika". Orłowa informowała o podziałach na grupy literackie w Polsce. Według Artura Sandauera, z którym rozmawiała, tworzyli je: 1. starzy pisarze, w części związani z „Kuźnicą” (Jarosław Iwaszkiewicz, Adam Ważyk, Mieczysław Jastrun); 2. ludzie roku 1949, socrealiści: Bohdan Czeszko, Andrzej Braun, Wiktor Woroszylski, Grzegorz Lasota; 3. moderniści, przedstawiciele „przeszłego”.

Orłowa spotkała się również z Władysławem Broniewskim, który był w „trudnym położeniu” („ciagle pije”). Miał powiedzieć jej: „Co mam robić, napisałem «Słowo o Stalinie», napisałem szczerze (iskrienno). Co mam teraz robić?".

$\mathrm{Na}$ koniec swej notatki autorka zauważała, że w Polsce rzucają się w oczy ,silne tendencje kosmopolityczne”. Jako naganny przykład podawała informację, że w jednym z tygodników drukowano książkę ,reakcyjnego dekadenta Franza Kafki Metamorfozy". W planach wydawniczych pojawiło się dużo dzieł autorów francuskich, niemieckich, angielskich przy braku reprezentacji literatur krajów socjalistycznych ${ }^{1}$.

O tym, że kryteria i ton tych ocen w najbliższych kilku latach nie uległy zasadniczym zmianom, przekonuje sprawozdanie W. Bykowa, attaché kulturalnego Ambasady ZSRR w Warszawie, z 11 kwietnia 1959 r. Jego zdaniem w 1958 r. na półkach księgarskich w Polsce pojawiło się mniej pamfletów z krytyką socjalizmu i ZSRR, ale z drugiej strony ukazały się dzieła znamionujące ,odchodzenie od rzeczywistości”. Polscy pisarze, szczególnie młodzi, kontynuować mieli w nich ślepe naśladownictwo naturalizmu i ,tzw. nadrealizmu” zachodnich dekadentów - awangardystów takich jak: Samuel Beckett, Albert Camus, Franz Kafka, Françoise Sagan i inni. Po tej drodze szli ,hłaskowcy” (hłaskoidy): Aleksander Ścibor-Rylski, Bohdan Czeszko, Jerzy Krzysztoń, Olgierd Terlecki i Jadwiga Kozłowska. Tej tendencji miał ulec również „stary Iwaszkiewicz”, nie ustępując pod tym względem młodym.

W 1958 r. - kontynuował Bykow - nadal była wydawana literatura służąca rozrachunkowi z błędami i wypaczeniami (iskażeniami) przeszłości,

1 Rossijskij Gosudarstwiennyj Archiw Nowiejszej Istorii (dalej: RGANI), fond (dalej: f.) 5, opis (dalej: op.) 28, dieło (dalej: d.) 398, Otcziot [po 6 V 1956], k. 39-47. 
przedstawiająca tragedię polskich komunistów, akowców i narodu polskiego. Specjalizowali się w tym pisarze starszego pokolenia: Stanisław Wygodzki (Zatrzymany do wyjaśnienia) i Władysław Bartoszewski (książki o AK). Kolejny kierunek stanowić miała literatura kryminalna i ,irracjonalna” (Stanisław Dygat, Magdalena Samozwaniec), oceniana krytycznie, bo „odrywa czytelnika od realizmu socjalistycznego, problemów współczesności”.

Bykow twierdził, że jednostronnie przedstawia się polskiemu czytelnikowi piśmiennictwo zachodnie. Polskie wydawnictwa pod pretekstem odmowy wydawania bezkrytycznie każdego dzieła sowieckiego, które pojawiło się w ZSRR, szły po linii „dogodzenia drobnomieszczańskim gustom”. Niektóre z oficyn uznały za potrzebne zwrócenie się do „klasyków literatury rosyjskiej i sowieckiej" (Iwan Bunin, Borys Pilniak, Anna Achmatowa, wczesne utwory Ilii Erenburga). Zdecydowano się ,zrobić szum" (podniat szumichu) wokół powieści Wladimira Dudincewa Nie samym chlebem.

W Polsce nie przemilczano również niewygodnej dla kierownictwa sowieckiego sprawy Nagrody Nobla dla Borysa Pasternaka. Za ,zdrowe siły polskiej literatury" Bykow uznawał J. Putramenta, Igora Newerlego i L. Kruczkowskiego. „W tym kierunku” mieli również podążać Wojciech Żukrowski (Okruchy weselnego tortu), Kazimierz Brandys (Listy do pani Z.) i Lucjan Rudnicki (III tom Starego i nowego) oraz część młodych: Wanda Melcer (Aleja niepodległości) i Jerzy Lovell (Raport w sprawie aniołów).

Zdaniem Bykowa w literaturze polskiej rozpoczął się proces „otrzeźwienia", które było efektem działań kierownictwa partyjnego. Urzędnik ambasady zwracał uwagę na „wzmocnienie frontu ideologicznego”, które nastapiło po XII plenum KC PZPR (15-18 października 1958 r.), choć oceniał te deklaracje jako niekonsekwentne. Do takiej konstatacji Bykowa skłaniało wystapienie Jerzego Morawskiego na naradzie pracowników kultury w grudniu 1958 roku, na której miał on mówić, że partia popiera szeroko pojęte eksperymentowanie w dziedzinie twórczości artystycznej, w tym w literaturze. Podobne opinie miał głosić również minister kultury i sztuki Tadeusz Galiński.

W ZLP zdaniem Bykowa od 1956 r. kierownictwo objęła grupa Antoniego Słonimskiego, do której zaliczał m.in. M. Jastruna, Pawła Hertza i Juliusza Żuławskiego. Rozkręcili oni „wredną w sensie politycznym robotę, walcząc o tzw. integralną demokrację, a w szczególności o możliwość swobodnego wyrażania antysocjalistycznych reakcyjnych poglądów". Grupa ta działała przeciwko partyjnej organizacji literatów. Ta ostatnia też nie zyskała przychylnej oceny - mieli w niej odgrywać coraz większą rolę rewizjoniści (P. Hertz i Jan Wyka). Bykow co prawda, in- 
formował swoich przełożonych o wyjściu z partii ,grupy popularnych pisarzy" (M. Jastrun, Jan Kott, A. Ważyk, J. Żuławski, P. Hertz, Jerzy Andrzejewski), ale o powodach tej decyzji nie wspominał.

Z gruntowną krytyką spotkał się w dokumencie przebieg zjazdu ZLP we Wrocławiu w dniach 15-16 grudnia 1958 r. Bykow wzmiankował o głośnym wystapieniu Stefana Kisielewskiego, który cytował spis pisarzy i dzieł niedopuszczonych do druku z przyczyn cenzuralnych. Wspominał również o P. Hertzu, który mówił o tym, że pisarz nie może zgodzić się z istnieniem cenzury. Attaché uznał rezolucję zjazdu za antypartyjną. Pochwalał krytyczne stanowisko kierownictwa partii wobec zjazdu, które znalazło odzwierciedlenie w komentarzu „Trybuny Ludu”, przedrukowanym 10 stycznia 1959 r. w czasopiśmie „Sowiecka kultura”. Z aprobata witał też zapowiedź Biura Politycznego KC PZPR dotyczącą dokonania kolejnej czystki w szeregach partyjnych ZLP².

Nastawiony na śledzenie ,politycznej niepoprawności” ogląd środowiska polskich literatów obowiązywał również w latach 60 . Znalazło to wyraz m.in. w notatce radcy Ambasady ZSRR w Warszawie G. Gołowienkowa z października $1965 \mathrm{r}$. Tematem pisma był tzw. memoriał Igora Newerlego ${ }^{3}$. Zdaniem radcy został on uchwalony pod wpływem rewizjonistów i zawierał życzenia oraz pretensje pisarzy zgłaszane do kierownictwa partyjnego i państwowego. Tym, co wzbudziło najwięcej kontrowersji, był fragment dotyczący cenzury. Stwierdzano, że nie opiera się ona na podstawach prawnych, istnieje anonimowo, nie ma możliwości odwołania się od jej decyzji, które nie podlegają kontroli. Cenzura zauważano w tym dokumencie - wpływa na swobodę myślenia twórców, ogranicza ją. Radca informował również o pozostałych wysuniętych postulatach: zorganizowania funduszu literatury w celu udzielania pomocy socjalno-bytowej pisarzom i „rady związków twórczych” (w oryginale polskim memoriału mówi się o Radzie Twórczości Artystycznej) dla konsultowania decyzji w sprawach kulturalnych oraz o żądaniu wypłat 100\% honorariów przy wznawianych wydaniach dzieł. W konkluzji Gołowienkow stwierdzał, że według ocen ,przyjaciół” (tak nazywano w korespondencji sowieckiej polskich komunistów) zastosowanie ostrych środków wobec inicjatorów memoriału ,może tylko komplikować sytuację, dałoby Zachodowi powód do antypolskiej kampanii"4.

2 RGANI, f. 5, op. 36, jedinica chranienija (dalej: j.ch.) 94, rolik (dalej: r.) 5841, Posoł Ambrasimow - tow. Andropowu, 11 IV 1959, k. 4-15.

3 O memoriale szeroko pisze Konrad Rokicki: Literaci. Relacje między literatami a wladzami PRL w latach 1956-1970, Warszawa 2011, s. 322-351.

4 RGANI, f. 5, op. 36, j. ch. 149, K woprosu o „Memorialie” Warszawskogo Otdielenija Sojuza Polskich Pisatieliej, 4 X 1956, k. 133-136. 
Kwestie polityczne związane ze środowiskiem literackim w Polsce interesowały Moskwę szczególnie w 1968 r. W dokumentach postsowieckich można odnaleźć m.in. notatkę N. Michajłowa, przewodniczącego Komitetu do Spraw Druku (Komitet po pieczati) przy Radzie Ministrów ZSRR, będąca efektem rozmów, które przeprowadził w trakcie pobytu na Międzynarodowych Targach Książki w Warszawie od 22 do 24 maja 1968 r. Jego rozmówcami byli zarówno funkcjonariusze partyjni (sekretarz KC PZPR Artur Starewicz), jak i państwowi (dyrektor Wydawnictwa Książka i Wiedza Stanisław Wroński, minister kultury i sztuki Lucjan Motyka, wiceminister w tym resorcie Kazimierz Rusinek). Wszyscy oni deklarowali W sposób mniej lub bardziej otwarty poparcie dla oficjalnego stanowiska Władysława Gomułki w sprawie „syjonizmu”"

W innym dokumencie - notatce W. Stiepakowa, kierownika Wydziału Propagandy Komitetu Centralnego Komunistycznej Partii Związku Radzieckiego (KC KPZR) z 27 marca 1968 r. na temat sytuacji w Polsce szczególny powód do niepokoju uznano fakt, że wśród organizatorów „nieporządków” i wystapień antyradzieckich byli pisarze i twórcy, „,którzy zapomnieli, że klasa robotnicza Polski z pomoca prawdziwego przyjaciela ZSRR stworzyła materialne i społeczne warunki dla ich twórczości”, o czym nie powinni zapominać6.

Wiele wskazuje na to, że zainteresowanie Moskwy nie ograniczało się tylko do postaw politycznych pisarzy. Dotyczyło ono również konkretnych utworów, zwłaszcza wtedy, gdy uznawano, że mogą zawierać treści wrogie wobec ZSRR lub systemu komunistycznego. Hipoteza ta znajduje potwierdzenie $\mathrm{w}$ dwóch dokumentach.

Pierwszy, z lutego 1956 r., to rosyjski przekład opowiadania Wiktora Woroszylskiego Odwiedziny w Wilnie, który pierwotnie ukazał się w ,Życiu Warszawy" (1955, nr 261). Został on przesłany przez kierownika Wydziału Europejskiego sowieckiego Ministerstwa Spraw Zagranicznych do KC KPZR. Co ciekawe, utwór Woroszylskiego musiał wzbudzić dużo szersze zainteresowanie w kręgach najwyższej władzy na Kremlu, skoro w dokumencie tym znajdujemy informację, że ,na to opowiadanie powołuje się w liście z 19 listopada 1955 r. do Mołotowa [wówczas ministra spraw zagranicznych] tow. P[antelejmon]. K. Ponomarienko [ambasador ZSRR w Polsce]"' . Autorzy tej korespondencji nie ujawniaja, co ich w tym dziele szczególnie poruszyło. Najpewniej chodziło o podjęcie tematyki, która była traktowana za szczególnie wrażliwą w stosunkach polsko-sowieckich.

\footnotetext{
${ }^{5}$ RGANI, f. 5, op, 60, j. ch. 30, r. 969600 , Zapiska N. Michajłowa, 28 V 1968, k. nlb.

6 RGANI, f. 5, d. 19, r. 009693, Zapiska Stiepakowa, 27 III 1968, k. nlb.

7 RGANI, f. 5, op. 28, d. 398, Tow. Lesanowu, 9 II 1956, k. 1.
} 
Z dużo większym zainteresowaniem w kierownictwie sowieckim spotkała się powieść J. Andrzejewskiego Miazga. Tej sprawie poświęcony był obszerny dokument autorstwa Wiktora Czebrikowa, zastępcy przewodniczącego Komitetu Bezpieczeństwa Państwowego (KGB) skierowany do KC KPZR, z 18 stycznia 1971 roku$^{8}$. W notatce stwierdzano, iż według otrzymanych informacji ,nastawiony rewizjonistycznie” polski pisarz złożył w jednym z wydawnictw PRL swoją powieść ocenianą przez ,polskich przyjaciół” jako dzieło, ,prowokacyjne, otwarcie skierowane przeciwko Polsce Ludowej i ZSRR". W zawartej w cytowanym dokumencie charakterystyce Andrzejewskiego pisano o jego pochodzeniu z ,rodziny drobnoburżuazyjnej” i karierze przedwojennej. „W czasie okupacji - stwierdzano - do żadnej organizacji nie należał". Wspominano wstapienie autora do PZPR i przejście na „pozycje rewizjonistyczne”, co spowodowało oddanie legitymacji partyjnej w 1957 r. Uznawano go za jednego z organizatorów zbierania podpisów pod Listem 349. Czebrikow wzmiankował również o wrogiej władzy postawie Andrzejewskiego w marcu 1968 r. i poparciu dla ,praskiej wiosny". W notatce pisano, że twórca wyjeżdżał wielokrotnie za granicę i ,podtrzymuje związki z wydawnictwem emigracyjnym «Kultura» znanym ze swej działalności antysocjalistycznej”. W środowisku literackim miał być uważany za człowieka nieuczciwego. Według informacji „polskich przyjaciół” rękopis Miazgi udało się Andrzejewskiemu również wywieźć na Zachód i „ma być podobno wkrótce opublikowany”"10.

Do dokumentu zostało dołączone streszczenie powieści, dokonane przez tychże ,polskich przyjaciół”. Za najciekawszą część uznano będący integralną częścią powieści Dziennik, dotyczący wydarzeń społecznopolitycznych. Miazga - czytamy w tym streszczeniu - to ,życie społeczne w PRL, pełne [...] bezkształtnych anonimowych duchów, uczciwość ludzi zniewolonych i żyjących bez nadziei”. Przedstawiono również najważniejsze, budzące najwięcej kontrowersji „hasła powieści”: „rosyjski model komunizmu zrodzony z tradycji carskich"; ,dopóki nic się nie zmieni w Rosji, nic się nie zmieni w Polsce”; „Rosja to jedyny kraj europejski, który nie zaznał wolności”; ,agonia zdegenerowanego systemu” [PRL]; ,gnój, gnój i kupa gnoju” [o PRL].

Tak ,wnikliwe” zainteresowanie się dziełem Andrzejewskiego potwierdza jeszcze raz tezę, że kierownictwo kremlowskie było niezwykle

\footnotetext{
8 RGANI, f. 5, op. 68, d. 163, W. Czebrikow - KC KPZR, 18 I 1971, k. 1-3.

9 Na temat listu zob. m.in. J. Eisler, List 34, Warszawa 1993; K. Rokicki, dz. cyt., s. $259-305$.

10 O perypetiach związanych z wydaniem Miazgi w paryskiej „Kulturze” zob. J. Andrzejewski, Miazga, oprac. A. Synoradzka-Demadre, Wrocław-Warszawa-Kraków 2002, s. CVIII-CXXV.
} 
wyczulone na wszelkie „wrogie” akcenty w literaturze polskiej - zwłaszcza gdy pośrednio czy bezpośrednio dotykały ZSRR i komunizmu.

\section{Problemy wydawnicze}

Kwestie wydawnicze po raz pierwszy pojawiają się w analizowanym zbiorze dokumentów w 1954 r. W sporządzonym w grudniu tego roku podsumowaniu stanu wydań literatury polskiej w ZSRR stwierdzano, że do tego czasu opublikowano tam 440 dzieł 67 polskich autorów o łącznym nakładzie około $10 \mathrm{mln}$ egzemplarzy. Mimo to okazało się, że polska książka literacka w ZSRR jest rzadkością. Ubolewano, że nie wydano dotychczas utworów, które niewątpliwie zainteresowałyby sowieckiego czytelnika: Obywateli K. Brandysa i Władzy Tadeusza Konwickiego. W tym samym czasie ukazały się dzieła niebudzące większego zainteresowania - np. Opowiadania Macieja Słomczyńskiego. Druk wielu innych utworów przeciagał się, jak Pamiatki z Celulozy I. Newerlego i Biegu do Fragala Juliana Stryjkowskiego. Za zaniedbanie uznawano niezakończenie wydania Dziet zebranych Adama Mickiewicza. Postulowano - w związku ze 101 rocznicą śmierci wieszcza - dokończenie tej edycji oraz publikację wyboru jego utworów i krytyczno-literackiego szkicu o życiu i twórczości Mickiewicza. Cytowany dokument zawierał również spis dzieł polskich autorów rekomendowanych do wydania w ZSRR. Zestaw zawierał teksty zarówno młodych socrealistów, jak i starszych pisarzy ocenianych jako mieszczących się w dopuszczalnych przez władze kanonach twórczości. Wśród tych pierwszych znalazła się m.in. już wcześniej wzmiankowana Władza T. Konwickiego, Pamiatka z Celulozy I. Newerlego oraz Obywatele K. Brandysa. Sowieccy decydenci umieścili na tej liście również m.in. Jaworowy dom Wilhelma Macha, Z pamiętnika korespondenta wojennego Janiny Broniewskiej, Między wojnami K. Brandysa, Kształt miłości Jerzego Broszkiewicza, Wrzesień Jerzego Putramenta oraz Drewniany różaniec Natalii Rolleczek. Z pisarzy o uznanej pozycji na listę wciagnięto jedynie uznawane za socrealistyczne opowiadanie J. Iwaszkiewicza Ucieczka Felka Okonia, Noce i dnie Marii Dąbrowskiej i Dziewczęta z Nowolipek Poli Gojawiczyńskiej ${ }^{11}$.

Władcy Kremla interesowali się nie tylko tym, jakie utwory literatury polskiej należy tłumaczyć na rosyjski, lecz także jakie książki autorów sowieckich winny ukazać się w PRL i innych krajach bloku wschodniego. Świadczy o tym pochodząca z kwietnia 1968 r. lista dzieł współczesnej

11 RGANI, f. 5, op. 162, r. 5109, Tow. Pospiełowu. Ob izdanii w SSSR polskoj litieratury, 31 XII 1954, k. 120. 
literatury sowieckiej rekomendowanych do wydania w krajach socjalistycznych. Zawierała ona kilkadziesiąt pozycji. Dominowały wśród nich utwory umacniające kult Lenina, zawierające kanoniczną wersję historii oraz współczesności ZSRR. Znalazły się na tej liście działa Walentija Owieczkina, Wiktora Astafiewa, Borysa Galina i Wiktora Goliawkina ${ }^{12}$.

Zainteresowanie polskim ruchem wydawniczym owocowało zarówno sowieckimi „rekomendacjami” dotyczącymi publikowania dzieł sowieckich w Polsce i polskich w ZSRR, jak i generalnymi ocenami ruchu wydawniczego. Taki charakter nosi analiza przygotowana przez Ambasadę ZSRR w Polsce z listopada 1970 r. Notatka zaczyna się od szacunków dotyczących liczby tytułów książek i broszur oraz nakładów w ujęciu historycznym. Zdaniem autorów tego dokumentu w latach 1944-1945 wydano w Polsce 1107 tytułów książek i broszur o nakładzie 10,4 mln egzemplarzy, podczas gdy w 1950 r. odpowiednie liczby wynosiły - 1611 i 118,8 mln, w 1960 - 7305 i 94,3 mln, a w 1965 - 8509 i 91,6 mln. W końcu 1970 r. miały działać 43 wydawnictwa książkowe o łącznej produkcji 120 mln egzemplarzy książek i broszur.

Przyznawano, że w końcu lat 60. doszło do ożywienia działalności wydawniczej w związku z tak ważnymi rocznicami jak: 50-lecie odzyskania niepodległości, 50 rocznica powstania Komunistycznej Partii Robotniczej Polski, 25 rocznica powstania Polski Ludowej, 25-lecie wybuchu powstania warszawskiego, 30 rocznica najazdu hitlerowskiego na Polskę, 25 rocznica zwycięstwa nad Niemcami oraz 100 rocznica urodzin Lenina. Analiza skupiła się na negatywnych elementach tego ożywienia. Zwracano uwagę na obecną w publicystyce historycznej tendencję do obrony i usprawiedliwiania rządzących „burżuazyjną Polską” oraz ich polityki wewnętrznej i zagranicznej. Jako egzemplifikacja tej tezy posłużył cytat z drugiego wydania książki Andrzeja Micewskiego $W$ cieniu marszałka Piłsudskiego (Czytelnik, 1969) mówiący o tym, że Piłsudski był człowiekiem jednej idei - niepodległości. Autorzy dokumentu piętnowali próby apologii organizacji podziemnych.

Przedmiotem szczególnej krytyki było czwarte wydanie (Wiedza Powszechna, 1969) pracy Rok przed klęska Marii Turlejskiej. Oskarżano ja o „osobliwe wywyższanie Becka i usprawiedliwianie jego polityki zagranicznej”. Autorka, zaznaczano, ,w sposób uproszczony podchodzi do problemu antysowieckiego charakteru polityki zagranicznej przedwojennej Polski”. Turlejska negatywnie oceniała pakty podpisywane przez państwa

${ }_{12}$ RGANI, f. 5, op. 60, j. ch. 30, Spisok nowych proizwiedienij sowietskich pisatielej, 22 IV 1968. 
europejskie, w tym ZSRR z Niemcami, kwalifikując umowy jako wyraz polityki uspokojenia. Te „błędy” traktowano jako efekt niewłaściwej polityki wydawniczej, niedostatecznej kontroli przez odpowiednie organy rękopisów trafiających do wydawnictw. Panowała atmosfera „rozsławiania narodu polskiego", szczególnie w okresie II wojny światowej, co stworzyło przyjazny grunt dla tych, którzy ,chcą podgrzewać w narodzie manię wielkości z ciasno nacjonalistycznych pozycji”. Z przychylnością więc autorzy notatki pisali o zaostrzeniu cenzury w Polsce.

Jako pozytywy polityki wydawniczej wskazywano na wzrost liczby tytułów książek pisanych z pozycji „partyjnych” oraz opublikowanie dzieł Lenina i związanych z tematyką leninowską ${ }^{13}$.

Polski ruch wydawniczy był również obecny w analizowanych dokumentach jako fragment większej całości obejmującej cały blok wschodni. Jak już pisałem w innym miejscu, problem koordynowania publikacji w ramach obozu socjalistycznego był przedmiotem wielostronnych narad, organizowanych od lat $60 .{ }^{14}$

Udostępnione w RGANI materiały źródłowe świadcza, że taka narada przedstawicieli organów wydawniczych państw bloku wschodniego odbyła się w 1967 r. w Moskwie, a dwie wcześniejsze - w Budapeszcie i Sofii. Nieco więcej wiemy o kolejnym takim spotkaniu w dniach 2224 kwietnia 1968 r. w Smolenicach na Słowacji z udziałem delegatów z Bułgarii, Węgier, NRD, Mongolii, Rumunii, ZSRR, Czechosłowacji, Jugosławii i Polski. Warszawę reprezentował dyrektor Wydawnictwa Książka i Wiedza S. Wroński. Na naradzie omówiono kwestie wydawania książek w związku z rocznicami: 150 urodzin Karola Marksa, 100 urodzin Lenina i 25 zwycięstwa nad faszyzmem w Europie. Podzielono się informacjami na temat dotychczas podjętych przygotowań do tych rocznic. Dyskutowano również o planach wykorzystania - w celu propagandy tych wydarzeń - targów książki i wystaw organizowanych w latach 1969-1970.

Narada nie obyła się bez elementów napięcia politycznego związanego z ,praską wiosną”. Przedstawiciel Czechosłowacji najpierw nie chciał przyjechać na spotkanie, a gdy się już pojawił - wyraził watpliwości co do celowości wypracowania wspólnego dokumentu. Gdy mimo tego wspólne stanowisko wypracowano - uchylił się od jego podpisania.

W cytowanej notatce wskazano na słabe przygotowanie strony jugosłowiańskiej i polskiej do narady (brak takich niezbędnych dokumentów jak plany wydawnicze, propozycje imprez itp.). Wystapienie Wrońskiego

13 RGANI, f. 5, op. 62, d. 59, Ambasada ZSRR w Polsce, 17 XI 1970, k. 220-237.

14 D. Jarosz, Władza a ksiażka spoleczno-polityczna w PRL 1956-1989, ,Z Badań nad Książką i Księgozbiorami Historycznymi”, 7-8:2013/2014, s. 133-172. 
zawierać miało elementy krytyczne wobec organizatorów, co odebrano jako przejaw napięcia między Polską a Czechosłowacją. W przyjętych $\mathrm{w}$ trakcie spotkania rekomendacjach postulowano publikację wydawnictw w związku ze wskazanymi rocznicami. Uczestnicy mieli ponadto wymienić się planami dotyczącymi edycji w związku ze 100-leciem urodzin Lenina oraz mieli rekomendować swoim wydawnictwom opublikowanie albumu o wodzu rewolucji październikowej ${ }^{15}$. Kolejny zachowany dokument na temat spotkania tego typu gremium dotyczył narady kierownictw ruchu wydawniczego w krajach bloku wschodniego, jaka odbyła się w dniach 1-5 listopada 1971 r. w Pradze. Wzięli w niej udział przedstawiciele NRD, Węgier, Kuby, Mongolii, Polski (na czele z Aleksandrem Syczewskim, wiceministrem kultury i sztuki), Rumunii, ZSRR, Czechosłowacji i Bułgarii. Po raz kolejny dyskutowano kwestie wydawnicze związane z 100 rocznicą urodzin Lenina i 25-leciem zwycięstwa nad faszyzmem. W tajnej notatce stwierdzono, że podjęto wspólne środki w celu wydawania publikacji nastawionych ,,przede wszystkim przeciwko ideologii burżuazyjnej" oraz poświęconych zbliżającej się rocznicy 30-lecia zwycięstwa nad faszyzmem. Przyjęto również propozycję towarzyszy z Moskwy zorganizowania (w latach 1972-1973) w państwach bloku serii wystaw poświęconych 50-leciu oświaty sowieckiej.

W przeciwieństwie do ramowych i ogólnych rekomendacji z lat poprzednich na naradzie praskiej zawarto porozumienie o systematycznej koordynacji i uzgodnieniu działalności organów kierujących wydawaniem książek w związku z uczestnictwem w wystawach, targach książki, sympozjach, szczególnie tych przewidzianych w programie Międzynarodowego Roku Książki (1972). Przewidziano również zorganizowanie w 1972 r. w Moskwie spotkania przedstawicieli wydawnictw społeczno-politycznych i społeczno-ekonomicznych ,dla rozwiązania problemu wspólnych publikacji skierowanych przeciwko ideologii burżuazyjnej”.

I tym razem nie obyło się bez napięć politycznych: delegacja rumuńska nie zgodziła się na postulaty dotyczące koordynacji prac kierownictw ruchu wydawniczego państw socjalistycznych i wydawania wspólnych dzieł na temat koncepcji rewizjonistycznych. Przedstawiciele Rumunii nie przyjęli na siebie zobowiązania przeprowadzenia jakichkolwiek wielostronnych przedsięwzięć w dziedzinie wydawniczej ${ }^{16}$.

Scharakteryzowane dokumenty, mimo że najpewniej daleko niekompletne, świadczą o tym, że sprawy polskiego ruchu wydawniczego, lite126.

${ }_{15}$ RGANI, f. 5, op. 60, j. ch. 31, r. 969600, Zapiska Michajłowa, 26 IV 1968, k. $121-$ ${ }^{1}$ RGANI, f. 5, op. 63, d. 97, Zapiska Stykalina, 13 XI 1971, k. 182-185. 
ratury i pisarzy pozostawały niezmiennie w całym analizowanym okresie w kręgu zainteresowań wielu centralnych instytucji państwowych i partyjnych. Odpowiednie opracowania i notatki krążyły m.in. w komórkach sowieckiego Ministerstwa Spraw Zagranicznych, Komitetu Bezpieczeństwa Publicznego, Rady Ministrów. Część z pism była sporządzana przez służby Ambasady ZSRR w Warszawie. Wydaje się, że kierownictwo sowieckie nieźle orientowało się $\mathrm{w}$ tej problematyce. Oceny formułowane na tej podstawie były zgodne z polityczno-ideologiczną ortodoksją.

\section{Streszczenie}

\section{Sprawy książki polskiej i jej autorów w sowieckich dokumentach partyjnych z lat 1954-1971}

Podstawąźródłową poczynionych ustaleń są odtajnione archiwalia przechowywane w Rosyjskim Państwowym Archiwum Historii Najnowszej (Российский государственный архив новейшей истории - RGANI), pochodzące z zespołu akt sowieckiej partii komunistycznej. Wynika z nich, że sprawy książki polskiej były monitorowane przez Kreml w całym analizowanym okresie. W Moskwie interesowano się przede wszystkim polskimi literatami i ich twórczością pod katem odstępstw od ideologicznego schematu oraz sposobu przestawiana Rosji i ZSRR. Ponadto władze sowieckie analizowały i oceniały ruch wydawniczy w Polsce. Próbowano wpływać na ofertę wydawniczą książek polskich w ZSRR i radzieckich w Polsce, stosując mechanizmy porozumień zarówno dwustronnych, jak i wielostronnych (systematyczne narady organów wydawniczych państw bloku wschodniego).

Słowa kluczowe: literatura polska - książka polska - komunizm - ZSRR - blok wschodni.

\section{Summary}

\section{The Polish book and Polish authors in Soviet party documents, 1954-1971}

Archival research, upon which the article is based, was conducted in the Russian State Archive of Contemporary History (Российский государственный архив новейшей истории - RGANI), and encompassed the declassified materials from the fond of the Soviet Communist Party. The materials demonstrate 
that the Kremlin monitored closely issues concerning the book in Poland during the whole period in question. Moscow was predominantly interested in the Polish writers and their literary production from the point of view of its divergences with the communist ideological paradigm, and the way Russia and the Soviet Union were presented to the Polish public. Apart from that the Soviet authorities analysed and evaluated the Polish publishing sector. Efforts were undertaken to influence the publication of Polish books in the Soviet Union, and the Soviet literary output in Poland. To this end bilateral and multilateral agreements were negotiated and signed, during periodically conducted meetings of publishing officials from the Eastern Bloc.

Key words: Polish literature - Polish books - communism - Soviet Union Eastern Bloc 